\title{
Review the Effect of Omega 3 Supplementation on Severity and Frequency of Epilepsy
}

\author{
Naseh Pahlavani ${ }^{1 *}$, Daryoush Rostami ${ }^{2}$ and Fatemeh Ebrahimi ${ }^{3}$ \\ ${ }^{1}$ Department of Nutrition, Faculty of Medicine, Mashhad University of Medical Sciences, Mashhad, Iran \\ ${ }^{2}$ Department of Anesthesia, School of Paramedical Sciences, Zabol University of Medical Sciences, Zabol, Iran \\ ${ }^{3}$ Skull Base Research Center, Loghman Hakim Hospital, Shahid Beheshti University of Medical Sciences, Tehran, Iran \\ *Corresponding Author: Naseh Pahlavani, Department of Nutrition, Faculty of Medicine, Mashhad University of Medical Sciences, \\ Mashhad, Iran.
}

Received: October 29, 2019; Published: November 07, 2019

DOI: $10.31080 /$ ASNH.2019.03.0538

\begin{abstract}
Epilepsy (also known as a 'seizure disorder') is a chronic neurological disorder characterized by recurring seizures and occurs when the message delivery system becomes unbalanced and when there is not enough gamma amino butyric acid (GABA) as inhibitory neurotransmitter. Clinical and experimental investigations have demonstrated that the duration and frequency of epileptic seizures can be reduced as a consequence of long-term n-3 PUFA (poly unsaturated fatty acid) supplementation. The aim of the present study was review of the effectiveness of PUFA supplementation especially omega 3 fatty acid as adjunctive treatment for intractable focal or generalized epilepsy in humans studies.

Keywords: Epilepsy; Seizure; Omega 3; EPA; DHA; PUFA
\end{abstract}

\section{Introduction}

Epilepsy is a resulting from sudden bursts of electrical energy in the brain and these electrical discharges produce seizures which vary from one person to another in frequency and form [1]. If the signal goes through all of the brain, the person may shake all over, fall and lose consciousness [2]. Epilepsy (also known as a 'seizure disorder') is a chronic neurological disorder characterized by recurring seizures [3]. A seizure occurs when the message delivery system becomes unbalanced and when there is not enough gamma amino butyric acid (GABA), seizure is occur because of receiving neurons is flooded with signals [4]. Seizures are induced by the influx of sodium and calcium ions mediated by excitatory neurotransmitters such as aspartate and glutamate and also Seizure inhibition is mediated by chloride ions entry and potassium ion outflow mediated by GABAergic neurotransmitter [5] (Figure 1). The seizure causes that divided into two type generalized and partial include high fever, especially in infants, drug use, metabolic disturbances, head trauma, e.g., car accident, brain tumor, infection(meningitis), stroke, Genetic factor and complication of diabetes or pregnancy [6]. The characteristics of seizure are vary greatly and some known characteristics include; uncontrolled movements such as shaking of arms or legs, loss of consciousness, falling, staring into space (absences) mostly in children, appearing dazed, confusing and mumbling [7]. Intractability defined by Berg., et al. as failure of two appropriate anti-epilepsy drugs (AEDs) with the occurrence of at least one seizure per month for $>$ 18 months [8]. Approximately one-third of patients with epilepsy do not achieve seizure control with available drugs, and many pa- tients experience troublesome adverse drug effects [9]. Epilepsy is the second most common chronic neurological condition seen by neurologist In children 3-6/1,000 in most country worldwide and higher prevalence rates ranging 14 to 57 per 1000 in some African and South American countries $[10,11]$. The present study was designed to review the effectiveness of PUFA supplementation especially omega 3 fatty acid as adjunctive treatment for intractable focal or generalized epilepsy in humans studies.

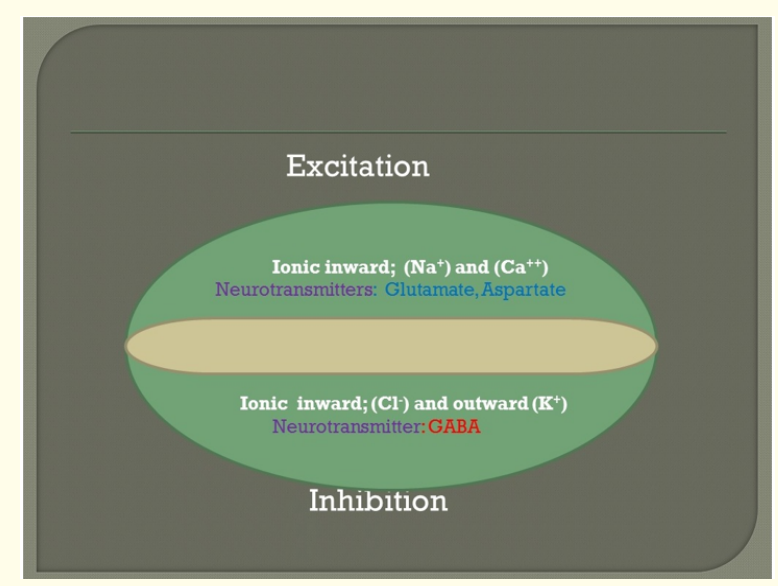

Figure 1: Cellular mechanism of seizure generation.

Role of PUFA and Omega 3 in epilepsy

Clinical and experimental investigations have demonstrated that the duration and frequency of epileptic seizures can be reduced as 
a consequence of long-term n-3 PUFA (poly unsaturated fatty acid) supplementation [12,13]. PUFAs (docosahexaenoic acid, 22: 6n-3) are major components of membrane phospholipids in brain tissue [14]. The PUFA role in the body cells is ant-inflammatory (reduced expressions of TNF- $\alpha$, IL-6, and cyclo-oxygenase-2), reduction of oxidative damage and inflammation, protection against ischemic injury and, neuro-protective bioactivity [15].

Several studies have been shown that omega-3 fatty acids reduce neuronal excitability and may be useful in the non-pharmacological treatment of patients with epilepsy [16].
In the present review in overall, most clinical trial studies have shown an inverse association between omega-3 supplementation and frequency and severity of seizure [12,17-19], however, in some studies these effects were not observed [20,21] (Table 1). In the non-randomized open labeled trial EPA and omega 3 supplementation in 10 patients with chronic epilepsy has not significant effect on epilepsy [22].

Conflicting results in some of studies probably due to Improper selection of control groups (For example, the soybean [Containing omega 3] or mineral oil[not specified combination]), small sample

\begin{tabular}{|c|c|c|c|c|c|c|c|c|}
\hline \multirow{2}{*}{$\begin{array}{l}\text { Author } \\
\text { (year), } \\
\text { Country }\end{array}$} & \multirow{2}{*}{$\begin{array}{l}\text { Age(year) } \\
\text { / Sex }\end{array}$} & \multirow{2}{*}{$\begin{array}{l}\mathrm{N} \text { (Inter- } \\
\text { vention/ } \\
\text { control) }\end{array}$} & \multicolumn{2}{|c|}{ Intervention type } & \multirow{2}{*}{$\begin{array}{c}\text { Duration } \\
\text { (week) }\end{array}$} & \multirow{2}{*}{$\begin{array}{l}\text { Outcome } \\
\text { measures }\end{array}$} & \multirow[b]{2}{*}{ Result } & \multirow[b]{2}{*}{ Note } \\
\hline & & & Intervention & Control & & & & \\
\hline $\begin{array}{l}\text { Alan Yuen } \\
\text { W.C., et al. } \\
\text { UK (2005) }\end{array}$ & $\begin{array}{l}19-65 \\
M / F\end{array}$ & $\begin{array}{c}57 \\
(29 / 27)\end{array}$ & $\begin{array}{c}1 \mathrm{~g} \text { of fish oils }(171 \\
\mathrm{mg} \text { EPA }, 112 \mathrm{mg} \\
\mathrm{DHA}), \text { and }<100 \mathrm{IU} \\
\text { vitamin } \\
\text { A and }<40 \text { IU vita- } \\
\text { min D }\end{array}$ & $\begin{array}{l}\text { Mixed oils (palm } \\
\text { olein } 70 \% \text {, } \\
\text { rapeseed oil } 15 \% \text {, } \\
\text { sunflower oil } \\
15 \% \text { ) }\end{array}$ & 12 & $\begin{array}{c}\text { Seizure } \\
\text { frequency }\end{array}$ & $\begin{array}{c}\text { Transiently reduced } \\
\text { seizure frequency } \\
24 / 22 / 24 \text { (int) } \\
31 / 25 / 28 \text { (con) }\end{array}$ & \\
\hline $\begin{array}{l}\text { Eduardo J., } \\
\text { et al. } \\
\text { Mexico } \\
(2011)\end{array}$ & $\begin{array}{l}4-16 \\
M / F\end{array}$ & 13 & $\begin{array}{c}\text { Combination } \\
\text { of omega } 3 \text { and } \\
\text { omega 6: (558 mg } \\
\text { EPA, 174mg DHA } \\
\text { and 60mg GLA }\end{array}$ & no treatment & 4 & $\begin{array}{c}\text { Seizure } \\
\text { frequency }\end{array}$ & $\begin{array}{c}\text { Decrease seizures } \\
\text { of } 26.61 \text { to } 5.92 \text { per } \\
\text { day }\end{array}$ & \\
\hline $\begin{array}{l}\text { Al Khayat., } \\
\text { et al. Egypt } \\
(2010)\end{array}$ & $\begin{array}{l}3-10 \\
M / F\end{array}$ & $\begin{array}{c}40 \\
(20 / 20)\end{array}$ & $\begin{array}{c}\text { PUFA: (700 mg } \\
\text { DHA, } 300 \mathrm{mg} \text { EPA) }\end{array}$ & no treatment & 24 & $\begin{array}{l}\text { Seizure } \\
\text { frequenc, } \\
\text { seizure } \\
\text { severity }\end{array}$ & $\begin{array}{c}\text { Significant decrease } \\
\text { in seizure frequency } \\
\text { F:3-50 per/month } \\
1-35 \text { per } / \mathrm{m} \\
\text { S:67-134 to } 37-68\end{array}$ & $\begin{array}{l}\text { Age, sex, } \\
\text { weight, } \\
\text { height } \\
\text { adjusted }\end{array}$ \\
\hline $\begin{array}{l}\text { Bromfield } \\
\text { E., et al. } \\
\text { USA (2007) }\end{array}$ & $\begin{array}{c}22-62 \\
M / F\end{array}$ & $\begin{array}{c}21 \\
(12 / 9)\end{array}$ & $\begin{array}{c}1.32 \mathrm{~g} \text { EPA, } 0.88 \mathrm{~g} \\
\text { DHA (EPA and DHA } \\
2.2 \mathrm{mg} / \text { day in a } 3: 2 \\
\text { ratio) }\end{array}$ & 2.2 mineral oil & 12 & $\begin{array}{c}\text { Seizure } \\
\text { frequency }\end{array}$ & $\begin{array}{l}\text { No effect on seizure } \\
\text { frequency } \\
\text { Int: } 15 \text { to } 11 \\
\text { Con: } 23 \text { to } 5\end{array}$ & - \\
\hline $\begin{array}{l}\text { DeGiorgio } \\
\text { Ch., et al. } \\
\text { USA (2008) }\end{array}$ & $\begin{array}{c}18-65 \\
M / F\end{array}$ & $\begin{array}{c}11 \\
\text { (cross } \\
\text { over) }\end{array}$ & $\begin{array}{l}1.7 \mathrm{~g} \text { EPA } 1.2 \mathrm{~g} \\
\text { DHA and }\end{array}$ & $\begin{array}{l}8 \text { capsules/ day } \\
\text { of soybean oil } \\
\text { placebo }\end{array}$ & 12 & $\begin{array}{l}\text { Seizure } \\
\text { severity, } \\
\text { seizure fre- } \\
\text { quency }\end{array}$ & $\begin{array}{l}\text { S.S: } 8.55 \text { to } 7.57 \text { (Int) } \\
8.55 \text { to }(\text { con) } \\
\text { S.F: } 11 \% \text { increased } \\
\text { in Int and } 14 \% \text { in- } \\
\text { crease in Control }\end{array}$ & $\begin{array}{l}\text { No ef- } \\
\text { fect on } \\
\text { seizure } \\
\text { frequen- } \\
\text { cy and } \\
\text { severity }\end{array}$ \\
\hline $\begin{array}{l}\text { Schlanger } \\
\text { S., et al. } \\
\text { Israel } \\
(2002)\end{array}$ & $\begin{array}{c}12-26 \\
M / F\end{array}$ & 5 & $\begin{array}{c}0.9 \mathrm{~g} \mathrm{EPA}, 2.3 \mathrm{~g} \\
\text { DHA }\end{array}$ & No treatment & 24 & $\begin{array}{c}\text { Seizure } \\
\text { frequency }\end{array}$ & $\begin{array}{l}\text { Reduced seizure } \\
\text { frequency } \\
5.25 \text { per/Wk to } 1 \\
\text { per/Wk }\end{array}$ & - \\
\hline
\end{tabular}

Table 1: Effects of n-3 PUFA on epilepsy in clinical trial studies.

size and Short duration of the study, neglecting other criterion for measurement of epilepsy Lack of attention to participant diets and levels of DHA and eicosapentaenoic acid (EPA) in the blood before and after intervention.

The probable mechanisms of the n-3 PUFAs act are 1-antagonizing neuro- inflammation (decrease the production of pro-in- flammatory prostaglandin E2 (PGE2) 2-DHA acts by modulating voltage-dependent and 3-ion channels and particularly the voltagedependent sodium channel (VDSC) and improvement of mitochondrial energy production are other proposed mechanisms [23,24]. The anticonvulsant actions of n-3 PUFA are shown in figure 2. 


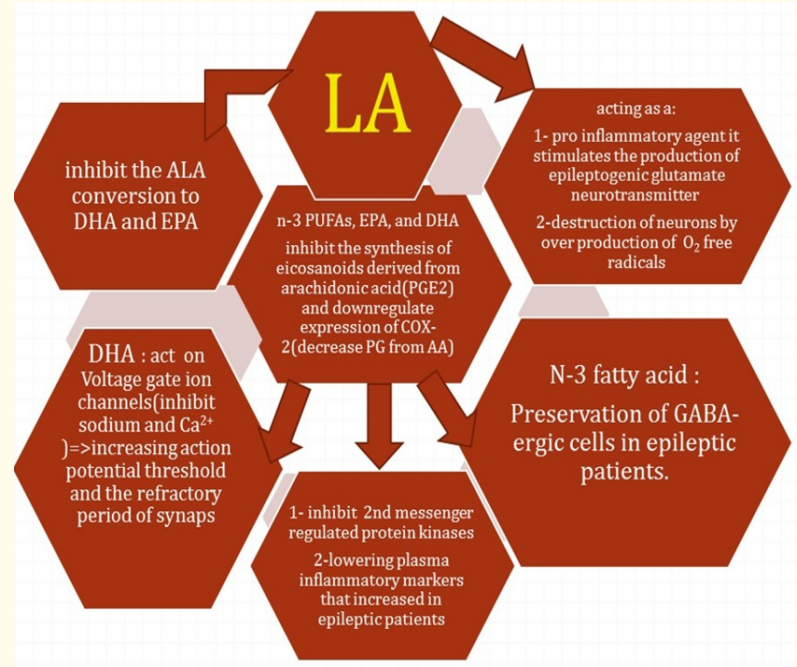

Figure 2: Anticonvulsant actions of n-3 PUFA.

ALA: Alpha-Linolenic Acid; LA: Linolenic Acid;

PG: Prostaglandin; COX: Cyclooxygenase; AA: Arachidonic Acid.

\section{Conclusion}

We conclude that nutrition is one of the factors affecting of epilepsy, in particular deficiency of DHA and EPA omega 3 fatty acids. We suggest that omega 3 fatty acids, as an essential nutrient is worthwhile trying as adjunctive therapy for patient with epilepsy especially in children. Additional well-designed and larger randomized controlled trials are required to establish optimal doses and to quantify the benefit of $n-3$ PUFA therapy in patients with epilepsy. The advantages of n-3 PUFA in epilepsy treatment are inexpensive and readily available that they have few side effects and $\mathrm{n}$-3 PUFA-enriched diet might serve as an adjunct to the drugs in patients with resistant seizures or as a first-line treatment in idiopathic epilepsy.

\section{Bibliography}

1. D’Ambrosio R., et al. "Functional definition of seizure provides new insight into post-traumatic epileptogenesis". Brain 132.10 (2009): 2805-2821.

2. Hauser WA and Beghi E. "First seizure definitions and worldwide incidence and mortality”. Epilepsia 49 (2008): 8-12.

3. Russ SA., et al. "A national profile of childhood epilepsy and seizure disorder". Pediatrics 129.2 (2012): 256-264.

4. Han Y., et al. "Modulating effect of hydrogen sulfide on gamma-aminobutyric acid B receptor in recurrent febrile seizures in rats". Neuroscience research 53.2 (2005): 216-219.

5. Kahle KT and Staley KJ. "Neonatal seizures and neuronal transmembrane ion transport". Jasper's Basic Mechanisms of the Epilepsies [Internet] 4th edition: National Center for Biotechnology Information (US) (2012).

6. Schelter B., et al. "Seizure prediction in epilepsy". Wiley Online Library (2008).
7. Nakayama K. "The Charactristics of Expressed Emotion (EE) in Families of Epileptic Patients-Focus on the Patients of Uncontrolled Seizures". Journal-Japan Epilepsy Society 21.1 (2003): 3-10.

8. Berg A., et al. "How long does it take for partial epilepsy to become intractable?" Neurology 60.2 (2003): 186-190.

9. Berg AT and Kelly MM. "Defining intractability: comparisons among published definitions”. Epilepsia 47.2 (2006): 431-436.

10. Bell GS., et al. "An unknown quantity-the worldwide prevalence of epilepsy". Epilepsia 55 (2014): 958-962.

11. Singh A and Trevick S. "The epidemiology of global epilepsy". Neurologic clinics 34.4 (2016): 837-847.

12. Schlanger S., et al. "Diet enriched with omega-3 fatty acids alleviates convulsion symptoms in epilepsy patients". Epilepsia 43 (2002): 103-104.

13. Reda DMA., et al. "Fish oil intake and seizure control in children with medically resistant epilepsy". North American journal of medical sciences 7 (2015): 317.

14. Farooqui AA and Horrocks LA. "Plasmalogens, phospholipase A 2, and docosahexaenoic acid turnover in brain tissue". Journal of Molecular Neuroscience 16 (2001): 263-272.

15. Zhang W., et al. "Omega-3 polyunsaturated fatty acid supplementation confers long-term neuroprotection against neonatal hypoxic-ischemic brain injury through anti-inflammatory actions". Stroke 41.10 (2010): 2341-2347.

16. Taha AY., et al. "Polyunsaturated fatty acids and epilepsy". Epilepsia 51.8 (2010): 1348-1358.

17. Yuen AW., et al. "Omega-3 fatty acid supplementation in patients with chronic epilepsy: a randomized trial". Epilepsy and Behavior 7.2 (2005): 253-258.

18. Barragán-Pérez EJ., et al. "Effectiveness of the use of an omega 3 and omega 6 combination (EquazenTM) in paediatric patients with refractory epilepsy". Journal of Epilepsy and Clinical Neurophysiology 17.4 (2011): 148-153.

19. Al Khayat HA., et al. "Polyunsaturated fatty acids in children with idiopathic intractable epilepsy: serum levels and therapeutic response". Journal of Pediatric Neurology 8.2 (2010): 175-185

20. DeGiorgio CM and Miller P. "n-3 fatty acids (eicosapentanoic and docosahexanoic acids) in epilepsy and for the prevention of sudden unexpected death in epilepsy". Epilepsy and Behavior 13.4 (2008): 712-723.

21. Bromfield E., et al. "A randomized trial of polyunsaturated fatty acids for refractory epilepsy". Epilepsy and Behavior 12.1 (2008): 187-190. 
22. Yuen AW., et al. "Non-randomized open trial of eicosapentaenoic acid (EPA), an omega-3 fatty acid, in ten people with chronic epilepsy". Epilepsy and Behavior 23.3 (2012): 370372.

23. Cysneiros RM., et al. "Qualitative analysis of hippocampal plastic changes in rats with epilepsy supplemented with oral omega-3 fatty acids". Epilepsy and Behavior 17.1 (2010): 3338.

24. Ferrari D., et al. "Neuroprotective activity of omega-3 fatty acids against epilepsy-induced hippocampal damage: quantification with immunohistochemical for calcium-binding proteins". Epilepsy and Behavior 13 (2008): 36-42.

\section{Volume 3 Issue 12 December 2019}

(C) All rights are reserved by Naseh Pahlavani., et al. 